\title{
Index system for water resources utilizability assessment during subway construction in water-rich weakly consolidated formation
}

\author{
${ }^{a}$ X. Bai, J. Liu, D. Liu, F. Wang \& C.J. Luo, b. W. Kang, C. Du \\ ${ }^{a}$ Faculty of Geosciences and Environmental Engineering, Southwest Jiaotong University, Chengdu, \\ Sichuan Province, 610031, China \\ ${ }^{\mathrm{b}}$ China Southwest Geotechnical Investigation \& Design Institute Co., Ltd, Chengdu, Sichuan \\ Province, 610081, China
}

KEYWORD: Subway; Groundwater; Utilizability; Index system; Evaluation mode

ABSTRACT: This paper develops an indicator system consisting of three criterion layers and 13 specific indicators. This indicator system can be used for water resources utilizability evaluation during subway construction in water-rich weakly consolidated formation. The weight of each index is determined by using Delphi and G1 methods, and the assessment criteria is constructed according to related standards, specifications and the practice of Chengdu subway construction. Jiulidilukou station of Chengdu Metro Line 7 is selected as a case study, and the results show that its water utilizability during the construction is excellent, which indicating that the water pumped from aquifer should be reused after some proper measures instead of wasting of water resources.

\section{INTRODUCTION}

With the development of society and economy, a great number of cities began to utilize underground space, which is regarded as an important way to solve population, resource and environment strain in urban areas (Li, Cai, \& Chen, 2014). Although subway has alleviated the current traffic congestion as many citizens choose this transportation, it has some adverse impact on environment. For example massive amount of groundwater discharges from the aquifer, emerging during subway construction, particularly, in a water-rich weakly consolidated formation. Groundwater mainly coming from dewatering from well-points and seepage in foundation pit during the construction of subway, can be used for agricultural, construction purpose, recharging, sprinkling green belt and restoring wetland(Garcia, \& Pargament, 2015; Alfranca, Garcia, \& Varela, 2011; Angelakis, \&Durham, 2008). Groundwater can also be used as non-drinking water for industrial enterprises, which facilitates the sustainable development of subway construction. It is an urgent problem to determine whether the groundwater possesses great utilizability during a subway construction.

This paper tries to solve this problem by establishing an index system to evaluate the utilizability of water resources during the subway construction in a water-rich weakly consolidated formation, and we take Jiulidilukou Station in Metro Line 9, Chengdu as a case study.

\section{EVALUATION MODEL FOR WATER RESOURCES UTILIZABILITY DURING SUBWAY CONSTRUCTION IN A WATER-RICH WEAKLY CONSOLIDATED FOMATION}

The assessment model mainly includes three parts: a) establishment of evaluation index system, b) determination of evaluation criteria and c) selection of evaluation method.

Evaluation index system

The total goal is broken down into three layers including engineering factors, hydrogeological conditions and water quality factors and many maneuverable indicators using goal decomposition method.

\section{Selection of engineering factors}

Subway projects have mutual influences on groundwater environment for its construction breaking the balance of groundwater, and groundwater hindering the projects construction. From an 
engineering point of view, sectional area, length of project, construction method, dewatering technology and waterproof measures are selected as characteristic indexes (Liu \& Liu. 2013).

Sectional area and length of project can reflect the size and catchment capability of the underground space. Construction method is a reflection of disturbance extent on groundwater environment during construction. Dewatering technology and waterproof measures directly determine pumping demands of groundwater during the subway construction. (Lu, \& Cui, 2008; Zhang, \& Li, 2007)

\section{Selection of hydrogeological conditions}

Hydrogeological condition is a major factor determining the quality and quantity of groundwater resources during the subway construction. Head pressures, permeability coefficient of surrounding rock and water yield property are chose as characteristic indexes (Zhang, \& $\mathrm{Li}, 2007$.).

Head pressure is a responding of the source power driving groundwater into subway space. Permeability coefficient of surrounding rock reflects the conductivity of rock and groundwater. Water yield property is a reflection of the continuing replenishment ability of the aquifer.

\section{Selection of water quality factors}

Reusing of water resources not only needs certain amount of water but also has requirements on water quality as security assurance. In Chinese standards of reclaimed water quality, such as GB/T 18920, GB/T 19923, GB/T 18921, Biochemical Oxygen Demand of 5 Day (BOD5), Suspended solid particles (SS), total dissolved solids (TDS), ammonia nitrogen $\left(\mathrm{NH}_{3}-\mathrm{N}\right)$, water odor and taste are the universal indexes. So they are selected as characteristic indexes for water quality.

Figure 1 is the evaluation index system for water resources utilizability during a subway construction.

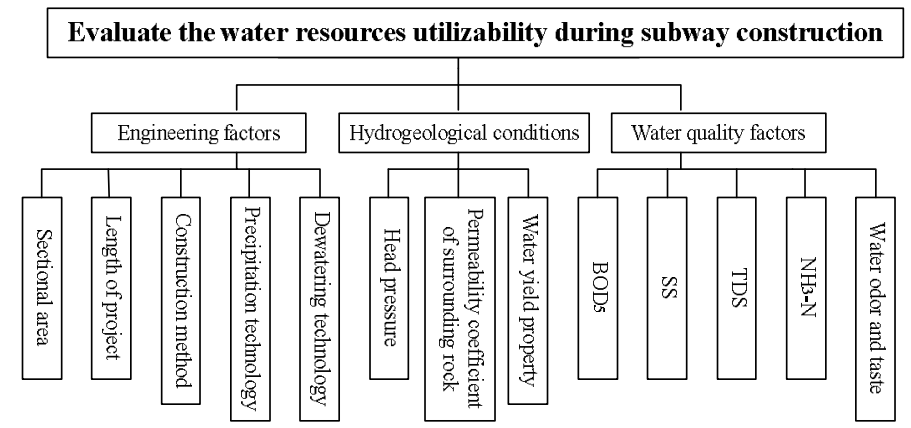

Figure 1. Evaluation index system for water resources utilizability during subway construction.

\section{Evaluation Criteria}

To ensure the precision and accuracy of evaluation, we set four grades, from high to low which represents excellent, good, medium and poor levels. By referring some related literatures, standards, norms, and combining the practice experience of Chengdu subway construction, the evaluation criteria are determined, as shown in table 1. 
Table 1. Evaluation criteria and grade classification

\begin{tabular}{|c|c|c|c|c|c|c|c|}
\hline \multirow{2}{*}{$\begin{array}{l}\text { Destinati } \\
\text { on } \\
\text { layer }\end{array}$} & \multirow{2}{*}{$\begin{array}{l}\text { Criteria } \\
\text { layer }\end{array}$} & \multirow{2}{*}{$\begin{array}{l}\text { Evaluating } \\
\text { indicator }\end{array}$} & \multirow[b]{2}{*}{ Unit } & \multicolumn{4}{|c|}{ Evaluation criteria } \\
\hline & & & & Excellent & Good & Medium & Poor \\
\hline \multirow{17}{*}{$\begin{array}{l}\text { [A] } \\
\text { Assessme } \\
\text { nt } \\
\text { index } \\
\text { system } \\
\text { for } \\
\text { water } \\
\text { resources } \\
\text { utilizabili } \\
\text { ty } \\
\text { of } \\
\text { subway }\end{array}$} & \multirow{8}{*}{$\begin{array}{l}{[\mathrm{B} 1]} \\
\text { Engineering } \\
\text { factors }\end{array}$} & $\begin{array}{l}{[\mathrm{C} 11] \text { Section }} \\
\text { al area }\end{array}$ & $\mathrm{m}^{2}$ & $>1200$ & $1200 \sim 200$ & $90 \sim 200$ & $<90$ \\
\hline & & $\begin{array}{l}\text { [C12]Length } \\
\text { of project }\end{array}$ & $\mathrm{m}$ & $>1000$ & $480 \sim 1000$ & $200 \sim 480$ & $<200$ \\
\hline & & $\begin{array}{l}\text { [C13]Constru } \\
\text { ction method }\end{array}$ & 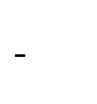 & $\begin{array}{l}\text { Open } \\
\text { excavation }\end{array}$ & $\begin{array}{l}\text { Mining } \\
\text { method }\end{array}$ & $\begin{array}{l}\text { Covered } \\
\text { excavation }\end{array}$ & $\begin{array}{l}\text { Shield } \\
\text { method }\end{array}$ \\
\hline & & $\begin{array}{l}\text { [C14]Dewate } \\
\text { ring } \\
\text { technology }\end{array}$ & - & $\begin{array}{l}\text { Well-point } \\
\text { dewatering }\end{array}$ & $\begin{array}{l}\text { Water-proof } \\
\text { curtains+ } \\
\text { well-point } \\
\text { dewatering }\end{array}$ & $\begin{array}{l}\text { Ming line } \\
\text { method }\end{array}$ & $\begin{array}{l}\text { Guidance } \\
\text { permeating }\end{array}$ \\
\hline & & \multirow[b]{4}{*}{$\begin{array}{l}{[\mathrm{C} 15] \text { Waterpr }} \\
\text { oofing } \\
\text { measures }\end{array}$} & \multirow[b]{4}{*}{ - } & \multirow[b]{4}{*}{$\begin{array}{l}\text { Primary } \\
\text { support/Wat } \\
\text { erproof of } \\
\text { segment }\end{array}$} & \multirow[b]{3}{*}{ Pre-grouting } & \multicolumn{2}{|c|}{$\begin{array}{c}\text { Diaphragm } \\
\text { wall panel }\end{array}$} \\
\hline & & & & & & Pre-grouting & trench + \\
\hline & & & & & & $+\quad$ Primary & pre-groutin \\
\hline & & & & & $\begin{array}{l}+\quad \text { Primary } \\
\text { support/Wate } \\
\text { rproof of } \\
\text { segment }\end{array}$ & $\begin{array}{l}\text { support/ } \\
\text { Waterproof } \\
\text { of segment+ } \\
\text { secondary } \\
\text { grouting }\end{array}$ & $\begin{array}{l}\text { g + Primary } \\
\text { support/ } \\
\text { - Waterproof } \\
\text { of } \\
\text { segment+ } \\
\text { secondary } \\
\text { grouting }\end{array}$ \\
\hline & \multirow{4}{*}{$\begin{array}{l}{[\mathrm{B} 2]} \\
\text { Hydrogeolog } \\
\text { ical } \\
\text { conditions }\end{array}$} & $\begin{array}{l}{[\mathrm{C} 21] \text { Head }} \\
\text { pressure }\end{array}$ & $\mathrm{MPa}$ & $>0.2$ & $0.05 \sim 0.2$ & $0.01 \sim 0.05$ & $<0.01$ \\
\hline & & $\begin{array}{l}{[\mathrm{C} 22] \text { Permea }} \\
\text { bility }\end{array}$ & & & & & \\
\hline & & $\begin{array}{l}\text { coefficient of } \\
\text { surrounding } \\
\text { rock }\end{array}$ & $\mathrm{cm} / \mathrm{s}$ & $>10^{\circ}$ & $10^{-2} \sim 10^{0}$ & $10^{-4} \sim 10^{-2}$ & $<10^{-4}$ \\
\hline & & $\begin{array}{l}{[\mathrm{C} 23] \text { Water }} \\
\text { yield property }\end{array}$ & $\mathrm{m}^{3} / \mathrm{d}$ & $>432$ & $86.4 \sim 432$ & $8.64 \sim 86.4$ & $<8.64$ \\
\hline & \multirow{5}{*}{$\begin{array}{l}\text { [B3] } \\
\text { Water } \\
\text { quality }\end{array}$} & {$[\mathrm{C} 31] \mathrm{BOD}_{5}$} & $\begin{array}{l}\mathrm{mg} / \\
\mathrm{L}\end{array}$ & $\leq 6$ & $\leq 10$ & $\leq 15$ & $\leq 20$ \\
\hline & & [C32]SS & $\begin{array}{l}\mathrm{mg} / \\
\mathrm{L}\end{array}$ & $\leq 5$ & $\leq 10$ & $\leq 20$ & $\leq 30$ \\
\hline & & [C33]TDS & $\begin{array}{l}\mathrm{mg} / \\
\mathrm{L}\end{array}$ & $\leq 300$ & $\leq 500$ & $\leq 1000$ & $\leq 1500$ \\
\hline & & {$[\mathrm{C} 34] \mathrm{NH}_{3}-\mathrm{N}$} & $\begin{array}{l}\mathrm{mg} / \\
\mathrm{L}\end{array}$ & $\leq 5$ & $\leq 10$ & $\leq 20$ & $>20$ \\
\hline & & $\begin{array}{l}\text { [C35]Smell } \\
\text { and taste }\end{array}$ & - & Tasteless & $\begin{array}{l}\text { Poor, difficult } \\
\text { to detect }\end{array}$ & $\begin{array}{l}\text { Weak, } \\
\text { detectable }\end{array}$ & discomfort \\
\hline
\end{tabular}

\section{Evaluation Methods}

General comprehensive evaluation methods include principal components analysis, planning decisions, the grey system theory, fuzzy mathematics methods, machine learning and other methods. Each one has its limitation and advantage. For the multi-level evaluation model proposed 
in this paper, we use the multi-level fuzzy comprehensive evaluation which combines AHP and Fuzzy Comprehensive Evaluation methods.

Firstly, the index weight is determined by using Delphi and G1 method (Guo, 2007), and indicators are quantized according to the evaluation criteria, and then the relative membership degree is calculated. Finally, the results of the evaluation are obtained by composition operations. Calculation steps are as follows:

1. Establish the factors set, selected evaluation factors: Factor set is composed of elements which based on a set of factors that influence the object evaluation, expressed as $U$ :

$\mathrm{U}=\left\{u_{1}, u_{2}, \ldots, u_{n}\right\}$

Among them, each element $u_{\mathrm{i}}(\mathrm{i}=1,2, \ldots, \mathrm{n})$ represents various factors, and each $u_{\mathrm{i}}$ have $n_{\mathrm{i}}$ indicators

$\mathrm{u}_{i}=\left\{u_{i 1}, u_{i 2}, \ldots, u_{i \mathrm{n}_{i}}\right\}$

These indicators have different degrees of ambiguity.

Evaluation set contains all possible evaluations results:

$\mathrm{V}=\left\{v_{1}, v_{2}, \ldots, v_{n}\right\}$

Each elements $v_{\mathrm{i}}(\mathrm{i}=1,2, \ldots, \mathrm{n})$ represents a possible evaluation result.

2. Determine weight set: several professionals are invited to determine the order of indicators of each layer, and to make a comparative judgment of importance between adjacent indexes. And then the weights of each indicator can be calculated by using the G1 methods (Ma \& Fan, 1999).

3. Calculation fuzzy relation matrix: determine the membership according to the evaluation criteria, and then constitute the fuzzy relation matrix $\mathrm{R}$.

4、 Fuzzy comprehensive evaluation: composition operations of weight vector and fuzzy relation matrix:

$$
\begin{aligned}
\mathrm{B} & =\mathrm{W} \text { oR }=\left(\begin{array}{llll}
w_{1} & w_{2} & \mathrm{~L} & w_{m}
\end{array}\right) \mathrm{O}\left(\begin{array}{cccc}
r_{11} & r_{12} & \mathrm{~L} & r_{1 n} \\
r_{21} & r_{22} & \mathrm{~L} & r_{2 n} \\
\mathrm{M} & \mathrm{M} & \mathrm{M} & \mathrm{M} \\
r_{m 1} & r_{m 2} & \mathrm{~L} & r_{m n}
\end{array}\right) \\
& =\left(\begin{array}{llll}
b_{1} & b_{2} & \mathrm{~L} & b_{n}
\end{array}\right)
\end{aligned}
$$

\section{EVALUATION MODEL FOR CHENGDU METRO LINE 7 JIULIDI INTERSECTION STATIO}

\section{Project Overview}

Jiulidilukou station sits at the junction of the first terrace and second Terrace of Minjiang River, which is located in the western flank of Sichuan plain. The ground is very flat and surrounded by dense buildings. Fu River is actually perpendicular to the station. In the scope of the project, the buried depth of groundwater table is around $499.0 \sim 502.25 \mathrm{~m}$. The formations from top to bottom are as below:

$\mathrm{Q}_{4}{ }^{\mathrm{ml}}$ : great majority is plain fill, with the thickness of $0.8 \sim 3.0 \mathrm{~m}$.

$\mathrm{Q}_{4}{ }^{\mathrm{al}}$ : great majority is clay, with the thickness of $0.7 \sim 3.0 \mathrm{~m}$.

$\mathrm{Q}_{4}{ }^{\mathrm{fgl}+\mathrm{al}}$ : majority is the medium pebble soil with some sandy lenses, in some places the thickness are over 30meters.

$\mathrm{K}_{2} \mathrm{~g}$ : great majority is moderate weathered mudstone, which with clear structure and weak water yield property. Figure 2 shows the geologic profile: 


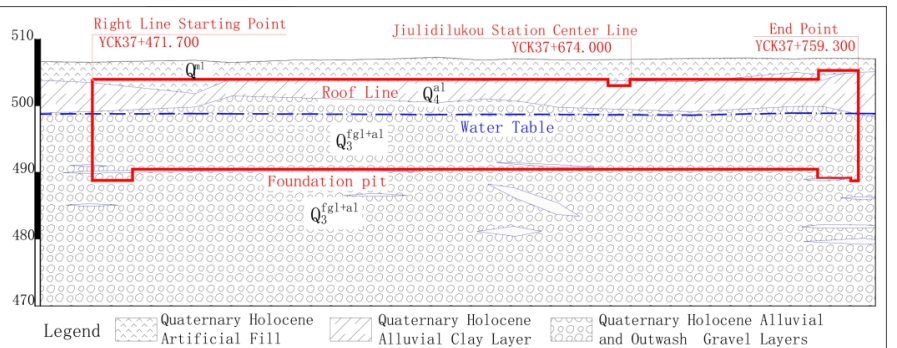

Figure 2. Sectional view of the project geology

Jiulidilukou station is in the middle of Chengdu Metro Line 7, belonging to the 'two underground island platform' station, with $12 \mathrm{~m}$-width and $140 \mathrm{~m}$ long platform. The outsourcing size of the station is $21.1 \mathrm{~m}$, and the outsourcing length of main part is $287.6 \mathrm{~m}$. Project plane layout is shown in Figure 3.

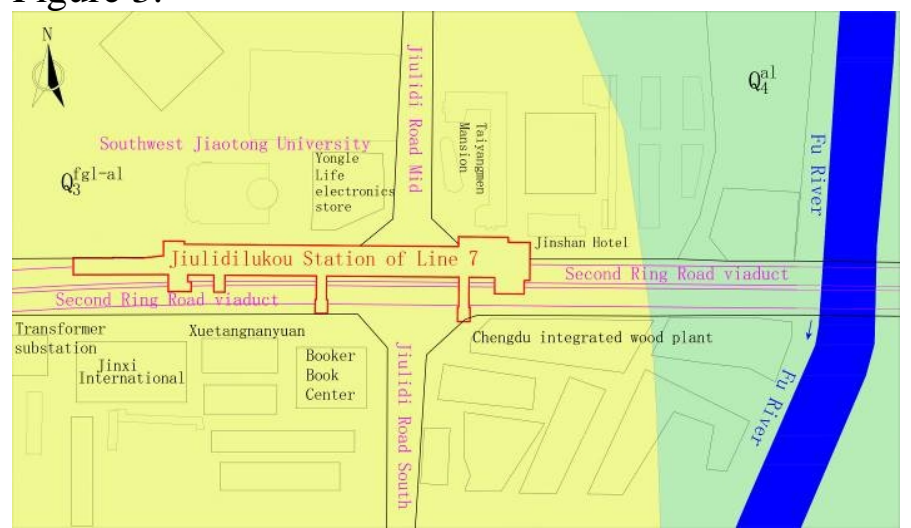

Figure 3. Project plane layout

Groundwater was dewatered using PVC tube well, with a diameter of $\varphi 300$, from 10 days before the excavation. Unfortunately, all the groundwater pumped from the wells drained to the local rain collection system after filtered.

\section{Evaluation of the utilizability of water resource in Jiulidilukou station}

The results of index quantification

Based on the design instruction, geological exploration report, and water quality analysis results of seepage in Jiulidilukou station, combining with the filed work, each index is quantified in Table 2. 
Table 2. Index quantification of Jiulidilukou station

\begin{tabular}{|c|c|c|c|}
\hline Indicator & Quantitation & Indicator & Quantitation \\
\hline $\begin{array}{l}{[\mathrm{C} 11] \text { Sectional area }(} \\
\left.\mathrm{m}^{2}\right)\end{array}$ & 280 & $\begin{array}{l}{[\mathrm{C} 23] \text { Water }} \\
\text { property }\left(\mathrm{m}^{3} / \mathrm{d}\right)\end{array}$ & 50311 \\
\hline $\begin{array}{l}\text { [C12]Length of project } \\
(\mathrm{m})\end{array}$ & 287.6 & {$[\mathrm{C} 31] \mathrm{BOD}_{5}(\mathrm{mg} / \mathrm{L})$} & 0.23 \\
\hline $\begin{array}{l}{[\mathrm{C} 13] \text { Construction }} \\
\text { method }\end{array}$ & Covered excavation & [C42]SS ( mg/L ) & $<5$ \\
\hline $\begin{array}{l}\text { [C14]Dewatering } \\
\text { technology }\end{array}$ & Well-point dewatering & [C43]TDS $(\mathrm{mg} / \mathrm{L})$ & 639 \\
\hline $\begin{array}{l}{[\mathrm{C} 15] \text { Waterproofing }} \\
\text { measures }\end{array}$ & $\begin{array}{l}\text { Diaphragm wall panel } \\
\text { trench }+ \text { pre-grouting }+ \\
\text { Primary support/ } \\
\text { Waterproof of segment+ } \\
\text { secondary grouting }\end{array}$ & {$[\mathrm{C} 34] \mathrm{NH}_{3}-\mathrm{N}(\mathrm{mg} / \mathrm{L})$} & 0.15 \\
\hline $\begin{array}{l}{[\mathrm{C} 21] \text { Head pressure }(} \\
\mathrm{MPa})\end{array}$ & 0.0835 & [C35]Smell and taste & Tasteless \\
\hline $\begin{array}{l}{[\mathrm{C} 22] \text { Permeability }} \\
\text { coefficient } \\
\text { surrounding } \\
(\mathrm{cm} / \mathrm{s})\end{array}$ & 20 & & \\
\hline
\end{tabular}

\section{Fuzzy comprehensive evaluation}

Weight of each indicator is obtained by using Delphi and G1 method:

$$
\begin{aligned}
W= & \left(\begin{array}{llll}
0.047 & 0.0330 .0330 .0650 .079 & 0.0760 .106 \\
& 0.1270 .0770 .0770 .0770 .1110 .092
\end{array}\right)
\end{aligned}
$$

Fuzzy relation matrix $\mathrm{R}$ of Jiulidilukou station is:

$$
R^{T}=\left(\begin{array}{ccccccccccccc}
0 & 0 & 0 & 1 & 0 & 0 & 1 & 1 & 1 & 1 & 0 & 1 & 1 \\
0 & 0 & 0 & 0 & 0 & 1 & 0 & 0 & 0 & 0 & 0.722 & 0 & 0 \\
1 & 1 & 1 & 0 & 0 & 0 & 0 & 0 & 0 & 0 & 0.278 & 0 & 0 \\
0 & 0 & 0 & 0 & 1 & 0 & 0 & 0 & 0 & 0 & 0 & 0 & 0
\end{array}\right)
$$

The evaluation result is calculated through compositing the index weight and fuzzy relation matrix:

$$
\mathrm{B}=\mathrm{W} \text { oR }=\left(\begin{array}{llll}
0.655 & 0.132 & 0.134 & 0.079
\end{array}\right)
$$

According to the results, we can see clearly that the utilizability of water resource during the construction of Jiulidilukou station of the 7th Chengdu subway is "Excellent", which means that draining it into the local rain collection system is a great waste of water resource and the laudable way is reuse it by taking some proper measures.

\section{CONCLUSION}

Establishing an index system for evaluating the utilizability of water resource during the subway construction is of great importance, especially when the project lies in a water-rich weakly consolidated formation.

Jiulidilukou station of Chengdu Metro Line 7 is selected as a case study in this paper, and the result of this case indicates that it has an excellent utilizability. After some proper measures, it can be reused instead of wasting of water resources. 


\section{ACKNOWLEDGEMENT}

This research was supported by the Fundamental Research Funds for the Central Universities (2682015CX020). Many thanks should be given to the team members related to this program, for their help with field investigation, data collection and processing.

\section{REFERENCES}

1) Alfranca, O. Garcia, J. \& Varela, H. 2011. Economic valuation of a created wetland fed with treated wastewater located in a peri-urban park in Catalonia. Water, Sci. Technol 63 (5): 892-899.

2) Angelakis, A.N. \&Durham, B. 2008 .Water recycling and reuse in EUREAU countries: trends and challenges. Desalination 218 (1):3-12.

3) Garcia, X. \& Pargament, D. 2015. Reusing wastewater to cope with water scarcity: Economic, social and environmental considerations for decision-making. Resources, Conservation and Recycling 101:154-166.

4) Guo, Y.J. 2007.Comprehensive evaluation theory / method and its application .China Science Press.

5) Li, J.H. Cai, H. \& Chen, J.S. 2014. Numerical analysis on the impact of foundation pit excavation on adjacent metro tunnel. EJGE, 19(S): 4439-4447.

6) Liu, J \& Liu, D. 2013. Theory and Practice for the negative effects of groundwater in karst tunnel evaluation. Beijing. China environmental press.

7) Lu, K.C. \& Cui, L.Q. 2008. Guide for tunnel waterproofing and drainage works. China Communications Press.

8) Ma, J. \& Fan, Z.P. 1999. A Subjective and Objective integrated approach to determine attribute weights. European Journal of Operational Research 112:397-404.

9) Zhang, J.L. \& Li, G.Q. 2007.Waterproof Construction and Design of City Subway Station. Construction Technology 36 (1):92-98. 